\title{
EDUCATIONAL STRATEGIES AND ROLES OF STAKEHOLDERS IN REDUCING ANTISOCIAL BEHAVIOR OF FOOTBALL SUPPORTERS
}

\author{
Arifuddin Usman ${ }^{1}$, Muhammad Adnan Hudain ${ }^{1}$, M. Said Zainuddin ${ }^{1}$, Gatot Jariono ${ }^{2}$, \\ Muhammad Miftah Fauzan ${ }^{1}$ \\ ${ }^{1}$ Universitas Negeri Makassar, Makassar, Indonesia \\ ${ }^{2}$ Universitas Muhammadiyah Surakarta, Sukoharjo, Indonesia \\ *e-mail: arifus1303@gmail.com
}

\begin{abstract}
This study aims to determine the strategies and roles of stakeholders in an effort to reduce antisocial behaviors of football supporters. This mixed-method study employed survey, interview and observation as the data collection techniques. A total of 60 participants consisting of 10 stakeholders and 50 football supporters were involved in this study. The qualitative data were collected through structured-interviews and field observations, while the quantitative data were obtained by administering questionnaires. The qualitative data analysis involved data display, data reduction, and conclusions, while quantitative data analysis used descriptive statistics and the mean difference test with one-way Anova. The results showed that the strategies to reduce antisocial behaviors of football supporters consisted of aggressive, religious, innovative, and fanaticism (ARIF) strategies. Stakeholders had six roles in an effort to reduce antisocial behaviors of football fans, namely: supporting fans' activities, giving ideas, consolidating with supporters, controlling, mediator, and giving consideration. These strategies and stakeholder roles were implemented through empowerment and education of the football supporters on a regular and ongoing basis so that antisocial behaviors change into good social behavior.
\end{abstract}

Keywords: strategies, roles, stakeholders, football supporters.

\section{STRATEGI PENDIDIKAN DAN PERAN PEMANGKU KEPENTINGAN DALAM MENGURANGI PERILAKU ANTISOSIAL PENDUKUNG SEPAKBOLA}

\begin{abstract}
Abstrak: Penelitian bertujuan untuk mengetahui strategi dan peran stakeholder dalam upaya mengurangi perilaku antisosial suporter sepakbola. Penelitian ini menggunakan metode survei dengan pendekatan campuran (mixed-methods) kualitatif dan kuantitatif. 60 orang partisipan yang terdiri atas 10 orang dari stakeholder dan 50 orang dari komunitas suporter sepakbola terlibat dalam penelitian ini. Pengumpulan data kualitatif dilakukan melalui wawancara terstruktur dan observasi lapangan, sedangkan data kuantitatif diperolah dari penyebaran kuisioner berbasis skala likert dengan skor 1-5. Analisis data kualitatif menggunakan tahapan display data, reduksi data, dan kesimpulan, sedangkan analisis data kuantitatif dengan statitik deskriptif dan uji perbedaan rata-rata dengan one-way Anova. Hasil penelitian menunjukkan bahwa strategi untuk mengurangi perilaku antisosial suporter sepakbola terdiri atas strategi Agresif, Religius, Inovatif, dan Fanatisme (ARIF). Stakeholder memiliki enam peran dalam upaya mengurangi perilaku antisosial suporter sepakbola, yaitu: pendukung kegiatan suporter, pemberi ide dan gagasan, konsolidasi dengan suporter, pengontrol, mediator, dan pemberi pertimbangan. Strategi dan peran stakeholder tersebut diterapkan melalui pemberdayaan dan pendidikan komunitas suporter sepakbola secara berkala dan berkelanjutan agar terjadinya perubahan perilaku antisosial menjadi perilaku sosial yang baik.
\end{abstract}

Kata Kunci: strategi, peran, stakeholder, pendukung sepakbola.

\section{INTRODUCTION}

The existence of football manifests itself not only in the matches played on the field. The presence of supporters coming from many different backgrounds in the stadium to support their favorite team is also an element that makes football an inclusive sport (C. Brown, 2020), making football one of the most popular sports in the world. There is a strong emotional bond among the football supporters/fans, football clubs and where the clubs exist (Fuller, 2017). Football fanatics view the sport as more than just aesthetic expressions of solidarity or ways to escape from boring routine; it is not just an entertainment or hobby either (Giulianotti, 2002). Many supporters believe that football plays a vital role in the 
collective expressions of identity, making the sport a magnificent spectacle. With that in mind, this research focuses not only on the technical factors of the game in the field, but also supporters who have also been the icon of the clubs (A. Brown, 1998).

Football industry revolution has been in conjunction with the ways the media portrays football. This relation is the result of three marketing methods implemented by sports media, including: evolution of digital media, workforce globalization and economy as well as cultural practice and identity (Boyle, 2010). Not all parties can immediately embrace this revolution. Enjoying the game 'intimately', supporters are among those who are against this modernization.

Supporters' rejection of this transformation, stems from their views that overcommercialization of the sport has led to the loss of values, identities, and cultures originally shared among the football fans community, making it an elite sport, not a sport that represents solidarity and loyalty (Millward, 2012). They believe sports media companies have allegedly undermined romanticism they have nurtured while supporting their favorite clubs (Fuller \& Junaedi, 2018). Some of them even hate the easy-to-consume kind of football that is produced in a safe, clean, sterile place with tight security. Results of an ethnography study in Manchester, England, show that the bond between supporters and teams has been mobilized, leading to global capitalism practices in daily life (Porter, 2008). Fans' rejection has been manifested in actions such as violence and vandalism (Rookwood \& Spaaij, 2017). Such actions cause damage to properties, injury, and even fatalities.

Supporters who demonstrate the tendency to commit antisocial actions is often referred to as hooligans. This label originally refers to England supporters who, back in the 1960s, gained a reputation for causing riots in football matches (Giulianotti, 2002). The hooligan move-ment has created a room for violence among football supporters (Krahé, 2020). Football hooliganism is also perceived as an antisocial behavior towards other groups, particularly supporters of the opposing team, security personnel, and public facilities (Clarke, 2003). This phenomenon was portrayed by, after viewing how football supporters were seen as a group of people with the biggest capacity manifested in hate and vandalism. Supporters argue that togetherness and the spirit of helping other group members are manifested in their presence in the stadium to support their favorite club and in the riots they are involved. This movement may have rooted in 'the England disease', but this practice has been reported as social issues in many countries (Rookwood \& Spaaij, 2017). Supporters' actions have drawn both positive and negative attention from the public and have been discussed in many studies. (Dunning, 2000) who viewed this phenomenon through sociological perspective stated that football hooliganism is a worldwide phenomenon influenced by certain social cultures. More recent studies have attempted to identify universal tendencies in the hooliganism movement, includeing joy and pleasant emotional desire, tough masculinity, territorial identification, individual and collective reputation management, a sense of solidarity and belonging, as well as representation of sovereignty and autonomy (Spaaij, 2008).

A sense of solidarity and belonging among football supporters has been a dominating variable. Research conducted in Bosnia-Herzegovina found that the unrest in Tuzla that ended in the resignation of the cantonal government was also a result of supporters' movement bringing up historical and gender issues (Gilbert, 2018). Football supporters are often seen as the identity of a city/region. A fieldwork by (Fuller \& Junaedi, 2018) successfully captured how three groups of supporters (Ultras) from different regions live in different cultural and political realities. Often remembered for their violent behavior, football supporters share the same dream of a better 'soccer-scape' in Indonesia. Indonesian football supporter communities display numerous beha-viors while supporting their favorite team in either home game or away game. Research results (Bayudewanto \& Junaedi, 2017; Effendy \& Indrawati, 2020; Hapsari \& Wibowo, 2015; Jariono \& Subekti, 2020; Syahputra, 2017; Warsa \& Bahfiarti, 2016) revealed that supporter communities use aggressiveness, creativity, and fanaticism to support their favorite clubs and promotes their communities' names. (Usman \& Herman, 2019) found a number of factors behind such behaviors which include motivation, loyalty, pride, togetherness, and mutual needs among fans.

The attitudes displayed by individuals or groups of supporters while supporting their favorite teams in the stadium are identified as 'ARIF' (aggressiveness, religiosity, innovative behavior, and fanaticism) (Usmana \& Agustangb, 2020). Such attitudes can be manifested in both positive and negative actions. Development of modern football must be accompanied by changes in the 
negative stigma attached to supporters. Therefore, education and involvement of multiple stakeholders are critical in the supporter development process. Previous research found a group of supporters that made a positive impact in delivering a 'propaganda' to grow and nurture love for the team (Niatami et al., 2020). Other studies found that educating other fellow supporters in the same group while acculturating both local and foreign cultures to the group can stimulate creativity in the way the group supports their favorite teams (Kusuma, 2017; Prasetiyo, 2020) .

There has been some research on education among the football supporter communities; however, the topics studied often focused solely on stakeholders' roles, including the clubs and the government, in educating football supporters. Therefore, this research attempts to investigate ways stakeholders introduce and implement 'ARIF' among supporters in Sinjai Football Association (Perssin). Educating supporters involves knowledge sharing, skills and capacity building, and motivation to increase their understanding of football rules so that they can act more wisely when supporting the team in either home game or away game. This research attempts to answer two main questions, include-ing: (1) what strategies are used to reduce the antisocial behavior of Perssin supporters? and (2) what roles stakeholders play in reducing the antisocial behavior of Perssin supporters?

\section{METHODS}

This survey research adopted a combination of qualitative and quantitative approaches. In mixed method research, quantitative analysis which provides descriptive statistics is followed by qualitative analysis that attempts to describe the phenomenon being explored (Onwuegbuzie \& Leech, 2005). With two data sources, one can be used to confirm the description generated using the other data source (Rallis \& Rossman, 2003).

This research involved stakeholders and Sinjai Football Association's supporter communities, and took place between April and May 2021. There were 60 participants including 10 stakeholders and 50 supporters selected based on certain criteria (purposive). Factors in selecting participants include: (a) supporters who actively come to the stadium to support Perssin team in matches; and (b) stakeholders, in this case security officers, who often interact with supporters and sports federation executives.
Data were collected through: (a) observation of Perssin supporters' activities, recorded on observation sheets (field notes); (b) semi-structured interview with selected participants; and (c) questionnaire distribution. In the semi-structured interview, an Indonesian Military (TNI) personnel and a police officer from security division were questioned, along with the head of the National Sports Committee (KONI), the head, secretary, and treasurer of the Youth and Sports Agency (Dispora) of Sinjai District to collect information relating to the roles of stakeholders in providing supporters with education and training needed. A semi-structured interview aims at digging up more information regarding strategies to reduce antisocial behavior of Perssin supporters while supporting the team from stakeholders' perspectives.

Questionnaires were sent out to stakeholders as well as Perssin's executive board and supporters to investigate strategies to wisely reduce antisocial behavior of the supporter communities from stakeholders' perspectives. The questionnaire involved ARIF indicators (aggressiveness, religiosity, innovative behavior, and fanaticism) and stakeholders' roles (support activities of supporters, give ideas, consolidate with supporters regularly, serve as a controller, act as a mediator, and give advice). Five-point Likert scale was adopted with options including: strongly agree, agree, undecided, disagree, and strongly disagree. The positive and negative statements in the questionnaire determined the score of each item.

Quantitative data were analyzed using descriptive statistics and one-way ANOVA techniques to rank indicators of strategy and roles of stakeholders from the highest to the lowest scores. Statistical analysis was performed using IBM SPSS 26 software. Qualitative analysis followed a procedure including interview transcript making, data reduction, analysis, data interpretation, and triangulation before drawing conclusion (Miles, Huberman \& Saldana, 2014).

\section{FINDINGS AND DISCUSSION}

\section{Findings}

\section{ARIF strategy to reduce supporters' antisocial} behavior

Based on Aggressiveness, Religiosity, Innovative behavior, and Fanaticism (ARIF) indicators, there are 12 items constructing supporters' antisocial behavior reduction strategy. Descriptive statistics of data collected from respondents is presented in Table 1 . 
Table 1. Descriptive Statistics of ARIF Indicators

\begin{tabular}{lccccc}
\hline Indicator & $\mathrm{N}$ & Mean & Standard Deviation & Minimum & Maximum \\
\hline Aggressiveness & 60 & 12.35 & 1.16 & 9.00 & 15.00 \\
Religiosity & 60 & 12.35 & 1.16 & 9.00 & 15.00 \\
Innovative & 60 & 13.45 & 1.23 & 10.00 & 15.00 \\
Fanaticism & 60 & 12.97 & 1.48 & 9.00 & 15.00 \\
Total & 240 & 12.78 & 1.34 & 9.00 & 15.00 \\
\hline
\end{tabular}

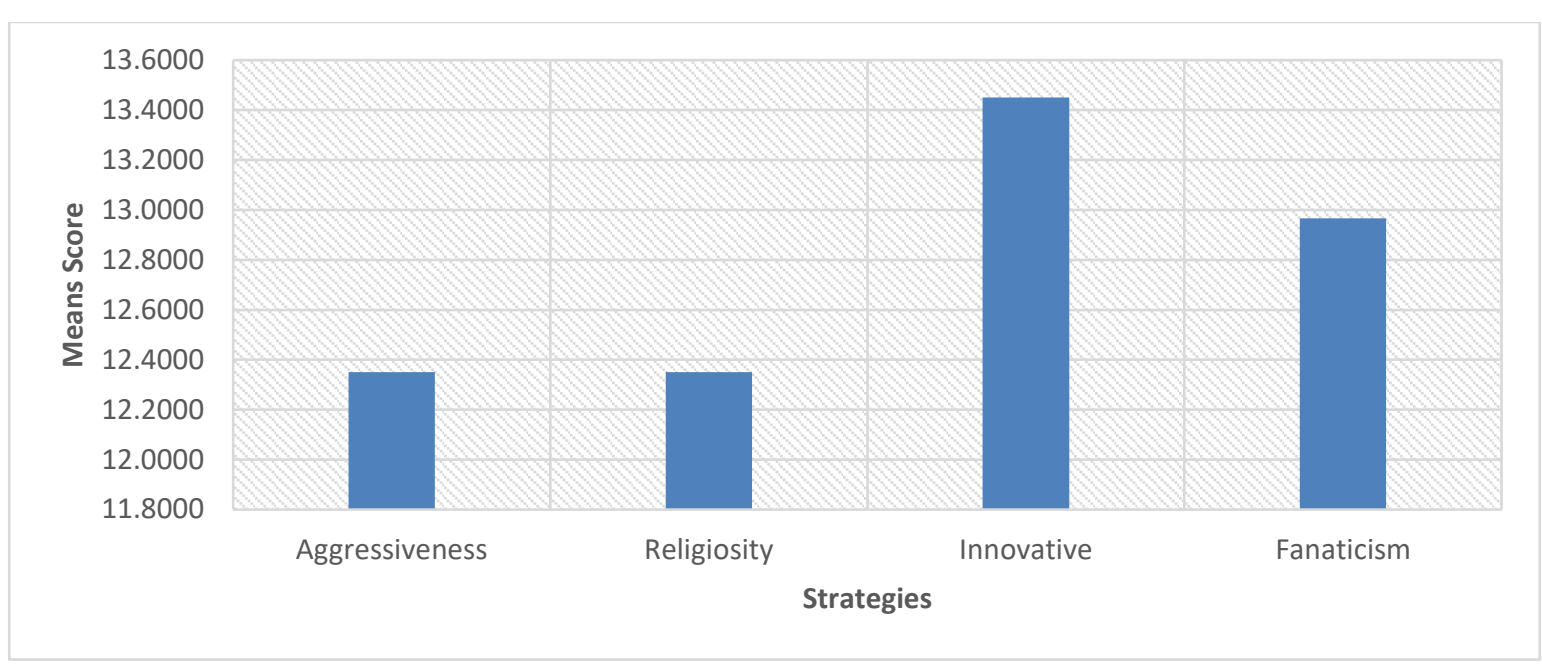

Figure 1. Strategy of supporter's community to reduce antisocial behavior

Table 2. Descriptive Statistics of Stakeholders' Roles

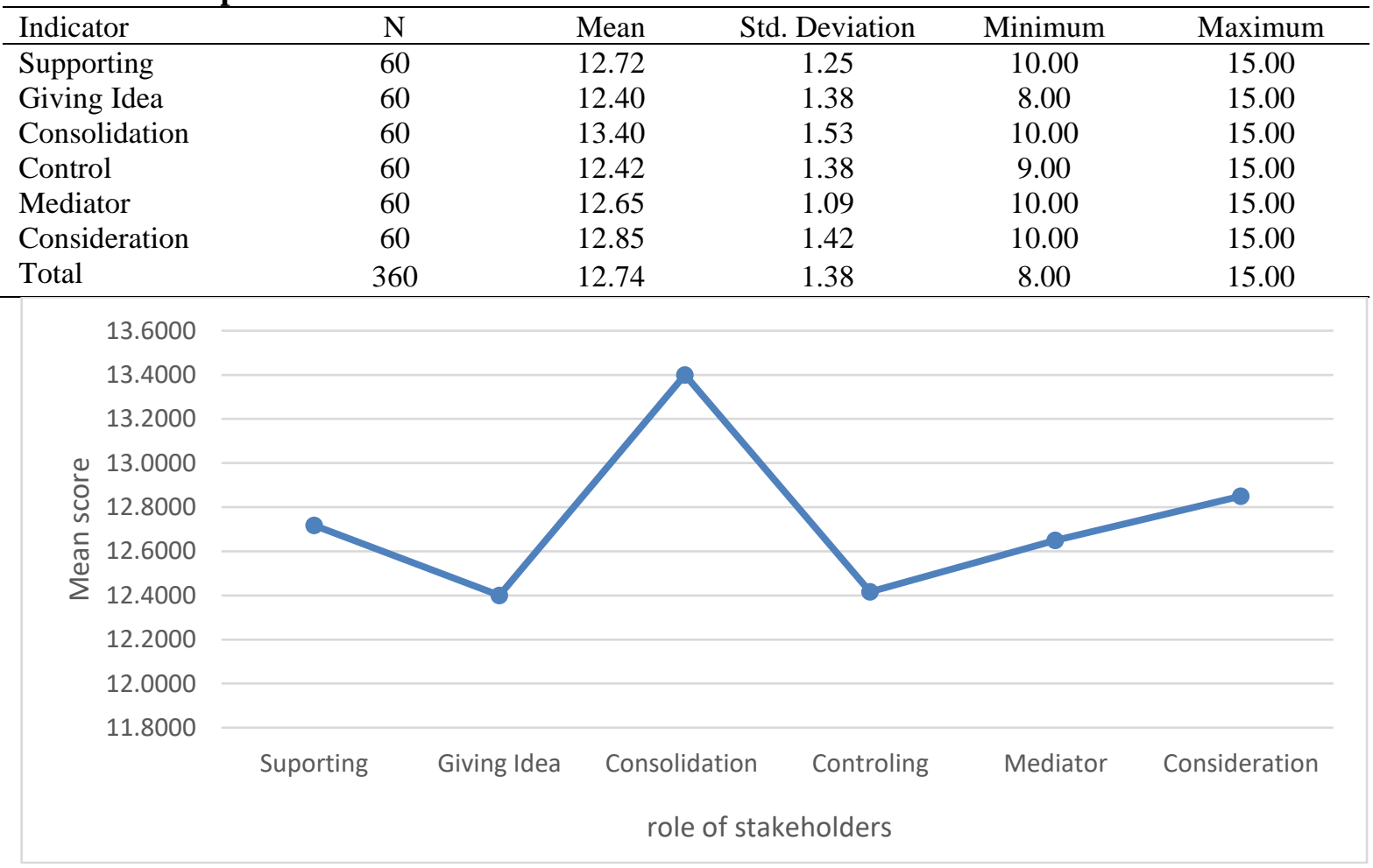

Figure 2. Role of stakeholders in reducing antisocial behavior of supporters

The one-way ANOVA results reveal a significant difference in ARIF indicators $(\mathrm{F}=10.656$, $\mathrm{p}=0.000$ ) as seen in Figure 1. As presented in Table 1, ARIF strategies in reducing supporters' antisocial behavior, from the highest to the lowest means, are Innovative behavior $(\mathrm{M}=13.45$, $\mathrm{SD}=1.23)$, Fanaticism $(\mathrm{M}=12.97, \mathrm{SD}=1.48)$, Religiosity $(\mathrm{M}=12.35, \mathrm{SD}=1.16)$ and Aggressiveness $(\mathrm{M}=12.35, \mathrm{SD}=1.16)$. 
The roles of stakeholders in reducing supporters' antisocial behavior

In reducing supporters' antisocial behavior, stakeholders play roles as supporter, idea generator, consolidator, controller, mediator, and advisor. Descriptive statistics of data collected from respondents is presented in Table 2 below.

One-way ANOVA results demonstrate a significant difference $(\mathrm{F}=4.646, \mathrm{p}=0.001)$ among means of the six roles of stakeholders in reducing supporters' antisocial behavior as can be seen in Figure 2. Referring to Table 2, the roles of stakeholders in reducing supporters' antisocial behavior, from the highest to the lowest means, are Consolidation ( $\mathrm{M}=13.40, \mathrm{SD}=1.53)$, Consideration $(M=12.85, S D=1.42)$, Supporting $(M=12.72$, $\mathrm{SD}=1.25)$, Mediator $(\mathrm{M}=12.65$, SD

$=1.09)$, Controlling $(\mathrm{M}=12.42, \mathrm{SD}=1.38)$, and Giving Idea $(\mathrm{M}=12.4, \mathrm{SD}=1.38)$.

Results of interviews with some supporters and stakeholders reveal that stakeholders play six roles in reducing supporters' antisocial behavior, which include: supporting supporters' activities, giving ideas, consolidating with supporters regularly, supervising, mediating, and giving advice.

\section{Supporting supporters' activities}

To reduce antisocial behavior of supporters, stakeholders play an important role in supporting football supporters' activities, increasing their knowledge of how to behave and act as supporters who prioritize local cultures while supporting their favorite team. In an interview, a supporter stated "with support from the government, particularly in how to understand social behavior wisely, supporters understand not only how to give support but also their tasks and functions as supporters better. They are also wiser and more tolerant towards supporters of the opposing team" (IKR, 21 April 2021). This is similar to what the "Capo", the Ultras' field general, stated "ultras are here to follow because we are "longing" (Interview, 21 March 2021).

As reducing antisocial behavior requires carefully made strategy, stakeholders can support supporters' activities to understand the rules of football, either inside or outside the field, in numerous ways. A public figure also stated "as Perssin's senior supporter, and as a public figure, I have always tried to give advice to new members so that they can maintain good behavior while supporting their favorite team, and understand how to give support in a football game better" (JSM, 21 March 2021). Similar to this, the head of the National Sports Committee (KONI) of Sinjai District, who is also Perssin's supporter community executive as well as a police officer, stated that, as a stakeholder, he has always given other supporters understanding of football rules so that people can show greater understanding and tolerance while supporting players in either home game or away game (SHD, 21 March 2021)

\section{Giving out ideas to supporter community}

The strategy to wisely reduce supporters' antisocial behavior through provision of ideas for innovative ways of supporting players in a football game can increase supporters' skills and knowledge of how to behave with kindness. Supporters revealed that "after receiving education, particularly about behavior, supporters can provide joyful support as can be seen from the innovation they make while giving support (SLM, interview, 20 March 2021). One of Perssin's supporters added "in this regard, social behavior education aims at shaping positive behavior" (MYS, interview, 20 March 2021). A public figure also supported this statement by saying "stakeholders' participation manifested in education for supporter community is considered excellent because, before supporting, without education, supporters will sing and cheer their favorite team, but they will not be organized nor skillful (JSM, interview, 20 March 2021).

Regular consolidation, supervision, and attention to football supporter community

Supporters have different abilities to understand football rules. Therefore, without oversight and education, supporters cannot be well organized while giving support. In an interview, a supporter stated that "after gaining knowledge of innovation and creativity in supporting their favorite team, supporters understand how to make support more exciting by understanding chanting, rhythmic clapping, and wave better" (DHR, 21 March 2021). Supporters come up with innovations to support the team that plays in either home or away matches. Continuous communication efforts initiated by the Youth and Sports Agency (Dispora) and KONI of Sinjai District have made Perssin's supporters feel acknowledged, encourageing them to be wiser and more compliant with the rules, especially during match day.

Mediation with supporter community concerning football rules

As a mediator, stakeholders are one of the sources of motivation to develop and educate supporter communities using a social behavior 
approach to encourage them to maintain positive behavior while supporting the team. A supporter stated that "supporters feel more excited when giving support of their own free will; we cheer so that the players can give their best performance" (MAR, 20 March 2021). Intrinsic motivation has driven supporter communities to be fully supportive of their favorite team. This interview results support findings of previous field observation showing how difficult it was for executives of Perssin's supporter community to encourage other community members to change aggressive behavior that has grown for so long within themselves.

Perssin's senior supporters indoctrinated junior members beforehand, telling them to choose ways that demonstrate good manners over anarchy while supporting the team. Continuous approaches by founders of supporter commu-nities successfully nurtured supporters' aggressiveness in supporting Perssin.

ARIF strategy and the roles of stake-holders in reducing antisocial behavior among football supporters in supporting the team are summarized in Table 3.

\section{Discussion}

Indonesian supporters have been carrying a stigma. This research attempts to investigate what roles stakeholders should play as well as what strategies are needed to reduce antisocial behavior. Involvement of stakeholders in reducing antisocial behavior is manifested in their actions which involve supporting supporters' activities, giving ideas, consolidating with supporters regularly, controlling, mediating, and giving advice. These findings provide real measures to reduce negative behavior of supporters. Defined oversight as how people obtain special abilities to help achieve organizational goals (Mathis, 2002). Furthermore, sports organizations need to encourage sports fans to participate in more positive activities to develop their communities (Yim et al., 2021). Therefore, this process is related to a range of goals of the company; meanwhile, oversight can be seen from both narrow and broad perspectives (Mathis, 2002). Oversight is a learning process through which a child obtains knowledge, skills, values, and norms to be part of the community (Nisrima et al., 2016). Oversight process can advance only if social interaction exists. Social interaction is a dynamic social relation which involves relationships among individuals, groups, and between individuals and groups. In the end, education for supporters is inevitable (Thomson \& Williams, 2014).

Stakeholders' involvement which manifests in oversight through education about social behavior among Perssin supporter communities has brought changes in social behavior, particularly due to implementation of siri' norms and values including sipakalebbi (respect), sipakainge (improve) and sipakatau (respect for fellow human beings) to build relationship among supporters before the game. This finding is similar to the findings of the research conducted by (Beddu et al., 2014; Darwis \& Dilo, 2013; Kaddi \& Dewi, 2017; Khotimah, 2013; Makbul et al., 2017; Rustan \& Cangara, 2011; Syarif et al., 2016) saying that siri' culture believes that shame is the way to maintain self-esteem through firmly held values of sipakatau, sipakainge, and sipakalebbi. Siri' is one of Bugis-Makassar cultures within which self-esteem, dignity, morality, and shame are firmly held, and those who hurt other people's self-esteem and dignity, bring shame, and break morality must be destroyed.

Table 3. The summary of ARIF strategy and roles of stakeholders

\begin{tabular}{|c|c|c|}
\hline & Indicator & Role \\
\hline \multirow[t]{4}{*}{ ARIF strategy } & Aggressiveness & $\begin{array}{l}\text { Understand the instructions given by the leader of the sup- } \\
\text { porter community }\end{array}$ \\
\hline & Religiosity & Prioritize the values and norms they hold \\
\hline & Innovative behavior & Support innovation in raising the players' spirits \\
\hline & Fanaticism & Be wherever the team plays to provide support \\
\hline \multirow{6}{*}{$\begin{array}{l}\text { Stakeholders' } \\
\text { roles }\end{array}$} & Support the activities & Provide supporters with support \\
\hline & Give ideas & $\begin{array}{l}\text { Always give ideas to help supporters understand their exist- } \\
\text { ence better }\end{array}$ \\
\hline & $\begin{array}{l}\text { Consolidate with supporters } \\
\text { regularly }\end{array}$ & $\begin{array}{l}\text { Consolidate with supporters so they can manage their com- } \\
\text { munity better }\end{array}$ \\
\hline & Control & Control the activities of supporter communities \\
\hline & Mediate & $\begin{array}{l}\text { Act as a mediator when the situation that involves supporters } \\
\text { is no longer conducive }\end{array}$ \\
\hline & Give advice & Give advice concerning provision of support \\
\hline
\end{tabular}


Despite stigma, Perssin supporters show willingness to open up to stakeholders as well as cooperative behavior and adaptive responses to the new era. They are now aware that their violent actions and vandalism will undermine their communities. Social behavior is described as one's awareness which determines one's concrete and repetitive actions to social objects (many people in a group) (Ahmadi, 2002). Weber proposed a transition from social actions to public social lives whose activities are classified into four. Moreover, Weber proposed that a democratic action occurs in situations in which multiple methods and purposes are available with people being able to choose any method solely for efficiency purposes; a rational action (value-rational) occurs when people choose certain methods by taking into account their efficiency in order to achieve excellence; an affective action occurs when methods and purposes of the action are driven by emotions; and a traditional action occurs when methods and purposes of the action are solely customary (Weber, 2013).

On the other hand, they believe that stakeholders take part in reducing antisocial behavior to support the development of social behavior. These data indicate that stakeholders' participation in reducing supporters' antisocial behavior has increased supporter communities' understanding about local conversion implementation, particularly in supporting their favorite team. In a similar, Usman found that aggressiveness, religiosity, innovative behavior, and fanaticism are the characteristics of Makassar Football Association (PSM) (Usman, 2018a; Usmana \& Agustangb, 2020). To develop PSM's supporters' social behavior, negative behavior must be controlled and turned into positive behavior including aggressiveness, religiosity, innovative behavior, and fanaticism (Usman, 2018b). Supporters' positive social behavior manifests in swift actions and fast reactions, along with trust, confidence in developing creativity, as well as innovation, pride and willingness to sacrifice when supporting the team in either home game or away game. In short, supporters' social behavior based on local wisdom can be developed by Perssin's supporters to support Perssin's players in the game.

\section{CONCLUSION}

Strategy for reducing Perssin's supporters' antisocial behavior is consisted of indicators namely aggressiveness, religiosity, innovative behavior, and fanaticism. In an attempt to reduce the football supporters' antisocial behavior,
Sinjai District stakeholders play roles as supporter of supporters' activities, idea generator, and regular consolidator between supporters, controller, mediator, and advisor. ARIF strategy and stakeholders' roles can be manifested through empowerment of football supporter community. Understanding football characteristics is a critical aspect to stress. Strategy and the roles of stakeholders, either through continuous approach or education, can change supporters' behavior, from antisocial to social. It is expected that future research can investigate the implementation of ARIF strategy more closely and expand the roles of stakeholders in reducing football supporters' antisocial behavior.

\section{REFERENCES}

Ahmadi, H. A. (2002). Psikologi sosial. Rineka Cipta.

Bayudewanto, A., \& Junaedi, F. (2017). Pola komunikasi organisasi pada Fans Club Juventini Boyolali dalam menjalin solidaritas (Studi deskriptif kualitatif tentang pola komunikasi organisasi pada fans Club Juventini di Boyolali). Universitas Muhammadiyah Surakarta.

Beddu, S., Akil, A., Osman, W. W., \& Hamzah, B. (2014). Eksplorasi kearifan budaya lokal sebagai landasan perumusan tatanan perumahan dan permukiman masyarakat Makassar. Prosiding Temul Ilmiah IPLBI. https://eng.unhas.ac.id/arsitektur/files/5ae0 ad4fceba7.pdf

Boyle, R. (2010). Sport and the media in the UK: the long revolution? Sport in Society, 13(9), 1300-1313. https://doi.org/10.1080/17430437.2010.51 0668

Brown, A. (1998). Fanatics!: Power, identity, and fandom in football. Psychology Press.

Brown, C. (2020). Football must not forget its inclusive responsibilities in the rush to get fans back into stadiums. Managing Sport and Leisure, 1-6. https://doi.org/10.1080/23750472.2020.18 58147

Clarke, D. (2003). Pro-social and anti-social behaviour. Routledge.

Darwis, R., \& Dilo, A. U. (2013). Implikasi Falsafah Siri' Na Pacce pada masyarakat Suku Makassar di Kabupaten Gowa. ElHARAKAH (TERAKREDITASI), 14(2), 186-225. 
https://doi.org/10.18860/el.v14i2.2317

Dunning, E. (2000). Towards a sociological understanding of football hooliganism as a world phenomenon. European Journal on Criminal Policy and Research, 8(2), 141162.

https://doi.org/10.1023/A:1008773923878

Effendy, M., \& Indrawati, E. S. (2020).

Hubungan antara empati dengan perilaku agresif pada suporter sepakbola Panser Biru Banyumanik Semarang. Empati, 7(3), 974-984.

https://ejournal3.undip.ac.id/index.php/em pati/article/view/21843

Fuller, A. (2017). Soccer and the city: the game and its fans in Solo and Yogyakarta. Sport in Society, 20(5-6), 675-688.

https://doi.org/10.1080/17430437.2016.11 58470

Fuller, A., \& Junaedi, F. (2018). Ultras in Indonesia: conflict, diversification, activism. Sport in Society, 21(6), 919-931. https://doi.org/10.1080/17430437.2017.13 00392

Gilbert, A. (2018). Tri vjere, jedna nacija, država Tuzla! Football fans, political protest and the right to the city in postsocialist Bosnia-Herzegovina. Soccer \& Society, 19(3), 373-399.

Giulianotti, R. (2002). Supporters, followers, fans, and flaneurs. Journal of Sport and Social Issues, 26(1), 25-46. https://doi.org/10.1177/019372350226100 3

Hapsari, I., \& Wibowo, I. (2015). Fanatisme dan agresivitas suporter klub sepak bola. Jurnal Psikologi, 8(1). https://ejournal.gunadarma.ac.id/index.php /psiko/article/view/1291

Jariono, G., \& Subekti, N. (2020). Sports motivation survey and physical activity students of Sport Education Teacher Training And Education Faculty FKIP Muhammadiyah University Surakarta. Kinestetik : Jurnal Ilmiah Pendidikan Jasmani, 4(2), 86-95. https://doi.org/10.33369/jk.v4i2.12449

Kaddi, S. M., \& Dewi, R. S. (2017). Sipakatau, Sipakainge, Sipakalebbi and Sipattokong as falsafah and value of local etnic Bugis (Intercultural communication studies of Bugis Perantau in Palu Central Sulawesi). Prosiding Konferensi Nasional
Komunikasi, 1(01).

https://doi.org/10.25008/pknk.v1i1.101

Khotimah, K. (2013). Pengamalan nilai

Sipakatau, Sipakalibbi, Sipakainge, di

lingkungan Forum Komunikasi Mahasiswa

Bone-Yogyakarta. THAQAFIYYAT: Jurnal

Bahasa, Peradaban Dan Informasi Islam, 14(2), 202-229.

http://202.0.92.5/adab/thaqafiyyat/article/v iew/1167

Krahé, B. (2020). The social psychology of aggression. Routledge.

Kusuma, A. T. (2017). Kreolisasi dalam kultur suporter sepakbola (Mimikri, hibriditas dan glokalisasi Brigata Curva Sud PSS Sleman). Jurnal Komunikasi, 11(2), 117136.

https://doi.org/10.20885/komunikasi.vol11. iss2.art2

Makbul, C., Harmaini, H., \& Agung, I. M. (2017). Self esteem, siri', dan perilaku agresif pada Suku Bugis: Sisi gelap self esteem tinggi. Jurnal Psikologi, 12(1), 8. https://doi.org/10.24014/jp.v12i1.3003

Mathis. (2002). Pembinaan dalam pembentukan perilaku. PT. Gaung Persada.

Millward, P. (2012). Reclaiming the Kop? Analysing Liverpool Supporters' 21st century mobilizations. Sociology, 46(4), 633-648.

https://doi.org/10.1177/003803851142555 7

Niatami, S. D., Luga, N., \& Rachmawati, O. (2020). Analisis program integrated communication komunitas Brigata Curva Sud (BCS) dalam membentuk kesadaran suporter sepak bola PSS Sleman. Jurnal Penelitian Dan Pengembangan Sains Dan Humaniora, 4(2), 109-117. https://doi.org/10.23887/jppsh.v4i2.27224

Nisrima, S., Yunus, M., \& Hayati, E. (2016). Pembinaan perilaku sosial remaja penghuni yayasan islam media kasih Kota Banda Aceh. Jurnal Ilmiah Mahasiswa Pendidikan Kewarganegaraan, 1(1). http://www.jim.unsyiah.ac.id/pendidikankewarganegaraan/article/view/483

Onwuegbuzie, A. J., \& Leech, N. L. (2005). On becoming a pragmatic researcher: The importance of combining quantitative and qualitative research methodologies. International Journal of Social Research Methodology, 8(5), 375-387. 
https://doi.org/10.1080/136455705004024 47

Porter, C. (2008). Manchester United, global capitalism and local resistance. Belgeo, 2 , 181-192. https://doi.org/10.4000/belgeo.10271

Prasetiyo, A. (2020). Subkultur ultras: identitas kaum muda dan peran media baru (Studi kasus pada kelompok ultras Brigata Curva Sud). DIMENSIA: Jurnal Kajian Sosiologi, 7(2), 83-102. https://doi.org/10.21831/dimensia.v7i2.326 52

Rallis, S. F., \& Rossman, G. B. (2003). Mixed methods in evaluation contexts: A pragmatic framework. Handbook of Mixed Methods in Social and Behavioral Research, 491-512.

Rookwood, J., \& Spaaij, R. (2017). Violence in football (soccer): Overview, prevalence, and risk factors. In The Wiley Handbook of Violence and Aggression (pp. 1-12). John Wiley \& Sons, Ltd Chichester, UK.

Rustan, A., \& Cangara, H. (2011). Perilaku komunikasi orang Bugis dari perspektif Islam. KAREBA: Jurnal Ilmu Komunikasi, 91-106.

https://journal.unhas.ac.id/index.php/kareb a/article/view/373

Spaaij, R. (2008). Men like us, boys like them: Violence, masculinity, and collective identity in football hooliganism. Journal of Sport and Social Issues, 32(4), 369-392. https://doi.org/10.1177/019372350832408 2

Syahputra, I. (2017). Religiusitas sepak bola dalam rezim media: Perspektif fans sepak bola Indonesia. Jurnal Ilmu Komunikasi, 14(2), 80-91. https://doi.org//10.31315/jik.v14i2.2122

Syarif, E., Sumarmi, S., \& Astina, I. K. (2016). Integrasi nilai budaya etnis Bugis Makassar dalam proses pembelajaran sebagai salah satu strategi menghadapi era Masyarakat Ekonomi Asean (MEA). Jurnal Teori Dan Praksis Pembelajaran IPS, 1(1), 13-21. https://doi.org/10.17977/um022v1i12016p 013

Thomson, E., \& Williams, R. (2014). Children as football fans: an exploratory study of team and player connections. Young Consumers, 15(4), 323-341.

https://doi.org/10.1108/YC-09-2013-00394

Usman, A. (2018a). Pengembangan perilaku sosial komunitas suporter Persatuan Sepakbola Makassar (PSM). Universitas Negeri Makassar.

Usman, A. (2018b). Developing supporter community of Makassar Football Association (PSM). Journal of Physics: Conference Series, 1028(1), 012186. https://doi.org/10.1088/17426596/1028/1/012186

Usman, A., \& Herman, H. (2019). Faktor-faktor yang mempengaruhi perilaku sosial suporter Perssin Sinjai di Kabupaten Sinjai. Seminar Nasional LP2M UNM, 1(1).

https://ojs.unm.ac.id/semnaslemlit/article/v iew/8157

Usmana, A., \& Agustangb, A. (2020). The implementation of "Arif" social behaviour within Perssin Supporters in Sinjai District. International Journal of Innovation, Creativity and Change, 11(3), 419-440. https://www.ijicc.net/images/vol11iss3/113 34_usman_2020_E_R.pdf

Warsa, A. W., \& Bahfiarti, T. (2016). Fenomenologi perilaku komunikasi suporter fanatik sepakbola dalam memberikan dukungan pada psm makassar. KAREBA: Jurnal Ilmu Komunikasi, 3(1), 1-7.

Weber, M. (2013). From Max Weber: essays in sociology. Routledge.

Yim, B. H., Byon, K. K., Baker, T. A., \& Zhang, J. J. (2021). Identifying critical factors in sport consumption decision making of millennial sport fans: mixed-methods approach. European Sport Management Quarterly, 21(4), 484-503. https://doi.org/10.1080/16184742.2020.17 55713 